\title{
Iodized salt, knowledge versus practice among females in Fayum governorate
}

\author{
Safaa Khamis Hassan, Nashwa Sayed Hamed, Shimaa Elsayed Mohammed \\ Mabrouk
}

Public Health and Community Medicine Department, Faculty of medicine Fayoum University

Submission Date: 2020-10-13 Revision Date: 2020-12-16 Acceptance Date: 2020-12-16

\begin{abstract}
Background: Iodine is observed as one of the most important trace elements in the human body, which is considered very essential during the synthesis of thyroid hormones. Iodine deficiency in humans can cause several diseases or problems, which include spontaneous abortion, increased infant mortality, cretinism, goiter, and mental defects. Objective: To evaluate the knowledge and practices of women toward the iodized salt. Method: A descriptive cross-sectional community-based study was conducted using a pre-tested structured interview questionnaire. Multi-stage cluster random sampling was used to select the study population which was 1789 women. Results: $55.4 \%$ of women reported a good knowledge score. Residence, history of thyroid disease, increasing level of education, and hearing about iodized salt were the significant predictors associated with good knowledge with odds ratios of 1.116, 2.405, 4.344 and 11.872 respectively. Conclusion: Although most of our studied participants $(87.1 \%)$ were using iodized salt, however knowledge about iodine and iodized salt was not satisfactory and many of the participants had improper practices related to the iodized salt usage
\end{abstract}

Keywords: Iodized salt, knowledge, practice, women

Corresponding author: Shimaa Elsayed Mohammed Mabrouk Email : shimaa.mabrouk@yahoo.com

\section{Introduction}

Iodine is a prime ingredient for thyroid function; it is needed in tiny amounts for normal growth, development, and wellbeing of all human beings. ${ }^{1}$ Iodine deficiency in humans can lead to many health problems as spontaneous abortion, increased infant mortality, cretinism, goiter, and mental defects. ${ }^{2}$

IDD is considered as a main public health problem worldwide due to its impact on many vulnerable groups of people such as children and lactating women. On a global scale, approximately 2 billion people suffer from ID of which approximately 50 million present with clinical manifestations. ${ }^{3}$ Deficient iodine in daily food intake may lead to insufficient thyroid hormone secretions with many clinical consequences, especially neurological feedback. ${ }^{4}$ Although it may affect any age, ID consequences may appear from the fetus stage, due to an insufficient iodine food intake in the mother's diet. So, the most vulnerable time is intrauterine and the natal phase where, discrimination, growth, and brain development may be affected by the inappropriate quantities of iodine and by the thyroid hormones with general consequences related to irreversible neurological disorders and mental retardation. ${ }^{5}$ Preventive measures to prevent IDD are necessary and should be 
taken into consideration, these measures include; salt iodization, the use of iodized oil, or the fortification of milk, bread, and water. Although all the efforts considered nowadays, there are still some ID areas and billions of people are suffering from IDD. ${ }^{6}$ The first-line strategy to secure adequate iodine intake by all individuals is global salt iodization which has been accepted as a safe and cost-effective measure. ${ }^{7}$ Owing to the strategy of iodine fortification by salt which is followed by many countries, severe iodine deficiency became a rare condition. However; mild-to-moderate iodine deficiency is still considered a major public health concern, even in some developed countries

In Egypt despite the implementation of a universal salt iodization program since 1996. and the demographic health survey (DHS), revealed that overall, $79 \%$ of Egyptian households were using adequately iodized salt. ${ }^{9}$ The prevalence of goiter is still high in Egypt (21.6 to $60.1 \%$ ) and Eastern Mediterranean countries. $^{10-11}$ In many developing countries including Egypt, despite the improvement of salt production and marketing technology, the quality of salt is still poor, incorrectly iodized or spoilt due to excessive exposure to moisture, light, heat, and contaminants. ${ }^{12,34}$ It is necessary to raise the awareness of the population about the importance of iodine to their health and periodic public health education for proper storage and usage of iodized salt should be continued. ${ }^{2}$ The aim of this study to evaluate the knowledge and practices of women toward the iodized salt.

\section{Method}

A community-based, cross-sectional descriptive study was carried out in Fayoum Governorate; The survey was conducted over six months between April and October 2019.
The participants included females 18 years old or more.

We used multi-stage cluster random sampling to select the study population. First, Fayoum governorate is divided into 7 districts: (Fayoum city, Fayoum district, Etsa district, Tamea district, Senoris district, Yousef elsedeq district, Ebshoy district). Each of them has urban and rural areas. We randomly assigned three districts (Fayoum district, Tamea, and Etsa). In the second phase, two regions or villages from each district were randomly selected. In the third phase, the prime street was chosen in the two regions, then proceed in one direction. In the fourth stage, the first house was chosen randomly, and then every other house. The Studied participants were all adult females who aged $\geq 18$ years and agreed to join in the study. If the family refused to participate in the survey we take the next house family.

A sample size of 1541 was calculated using open epi considering the following assumptions more than half of the respondent (56\%) knows about iodine deficiency disorder ${ }^{(2)}$, a design effect of 4 and confidence limit $95 \% \pm 5 \%$. The required sample size was increased by $15 \%$ to be 1800 .

Data of the study were collected with a pre-tested structured interview questionnaire. The questionnaire was adopted from previous studies ${ }^{(2,15) .}$ The questionnaire investigated the following themes:

1- Socio-demographic

characteristics of the interviewed female (age, residence, education, occupation, marital status, family history of thyroid diseases). monthly income level less than 1500 , from 1500 to 2000 and more than $2000 \mathrm{LE}^{(16,17)}$

2- Women knowledge about iodized salt (importance, how to store it, how and when to use it in cooking) 
Women practice regarding iodized salt use (how to store it, how and when to use it in cooking).

\section{Data analysis}

Data were collected, coded, and analyzed using Statistical Package for Social Table 1: Characteristics of study participants, Fayoum.

\begin{tabular}{|c|c|c|}
\hline Variables & $\begin{array}{c}\text { Number } \\
(\mathbf{1 7 8 9})\end{array}$ & Percent \\
\hline \multicolumn{3}{|l|}{ Age in years } \\
\hline $18-27$ & 649 & \\
\hline $28-37$ & 455 & \\
\hline $38-47$ & 419 & 25.4 \\
\hline$\geq 48$ & 266 & \multirow{3}{*}{$\begin{array}{l}23.4 \\
14.9\end{array}$} \\
\hline \multicolumn{2}{|l|}{$\underline{\text { Mean } \pm \text { SD }}$} & \\
\hline \multirow{2}{*}{\multicolumn{3}{|c|}{$\overline{34.33 \pm 11.35}$}} \\
\hline Residence & & \\
\hline Urban & 651 & 36.4 \\
\hline rural & 1138 & 63.6 \\
\hline \multicolumn{3}{|l|}{ Marital state } \\
\hline Married & 1474 & 82.4 \\
\hline unmarried & 315 & 17.6 \\
\hline \multicolumn{3}{|l|}{ Education } \\
\hline Illiterate & 270 & 15.1 \\
\hline Read and write & 184 & 10.3 \\
\hline Primary education & 136 & 7.6 \\
\hline \multicolumn{3}{|l|}{ Secondary education } \\
\hline \multirow[t]{2}{*}{ High education } & 568 & 31.7 \\
\hline & 631 & 35.3 \\
\hline Working & 701 & 39.2 \\
\hline \multicolumn{3}{|l|}{$\begin{array}{l}\text { The family income } \\
\text { per month }\end{array}$} \\
\hline$\leq 1500 \mathrm{LE}$ & 491 & 27.5 \\
\hline $1500-2000$ & 1045 & 58.4 \\
\hline$>2000$ & 253 & 14.1 \\
\hline $\begin{array}{l}\text { Having or having } \\
\text { family history of } \\
\text { thyroid disease }\end{array}$ & 238 & 13.3 \\
\hline \multicolumn{3}{|c|}{$\begin{array}{l}\text { Science (SPSS) software version } 16 . \\
\text { Simple descriptive-statistics in the form } \\
\text { frequencies and percentages were } \\
\text { calculated for numerical data. The Mean } \\
\text { and S.D were calculated for quantitative } \\
\text { variables in the form of simple } \\
\text { descriptive statistics. Non-parametric } \\
\text { tests (chi-square) and Binary logistic } \\
\text { regression were used. P < } 0.05 \text { was } \\
\text { considered statistically significant. }\end{array}$} \\
\hline
\end{tabular}

\section{Ethical considerations}

This study was approved by the Research Ethical Committee of Fayoum University. The questionnaires included explanations about the purpose of the study, confirmation of confidentiality of data, and assuring that it will never be used for purposes other than scientific research. A formal consent form was given to the participants. The participants were assured of confidentiality. To ensure privacy, respect, and honesty, the used questionnaire was-anonymous

\section{Results}

The data was collected from 1789 women. Most of them the age from 18 to 47 years old with a mean age, $34.33 \pm 11.35$, more than two thirds $(63.6 \%)$ of the participants were from rural areas. The majority $(82.4 \%)$ were married, and $(15.1 \%)$ of them were illiterate. $60.8 \%$ of participants were not working and $27.5 \%$ of them with a family income of less than 1500 LE. out of 1789 women, $238(13.3 \%)$ of them mentioned that there was a history of thyroid disease in their family. (Table 1) Many of the participants $(65.7 \%)$ heard or knew about iodized salt. Regarding knowledge about iodine element, $(65.3 \%)$ of the participants were aware that iodine is an essential element, and $(50 \%)$ knew that iodine is related to the thyroid gland. However, Only $12.8 \%$ of the participants were aware of the requirement of iodine, and $(41.3 \%)$ were aware that iodine is available in salt. Regarding the complications of iodine deficiency nearly half of the females $(54.2 \%),(47.8 \%)$ and $(53.2 \%)$ were not aware of the complication in pregnant women, in children and adults respectively (Table 2).

The study revealed that more than one third $(36 \%)$ knew how to identify the iodized salt bag, more than half of the participants $(59 \%)$ knew that humidity can affect the iodine in the salt bag. only 
$5.5 \%$ knew the shape of the healthy bag. Only $(19.4 \%)$ of the studied population knew about how to conserve iodized salt bag after opening. More than one-third of them $(36.7 \%)$ knew when salt should be used (Table 3 ).

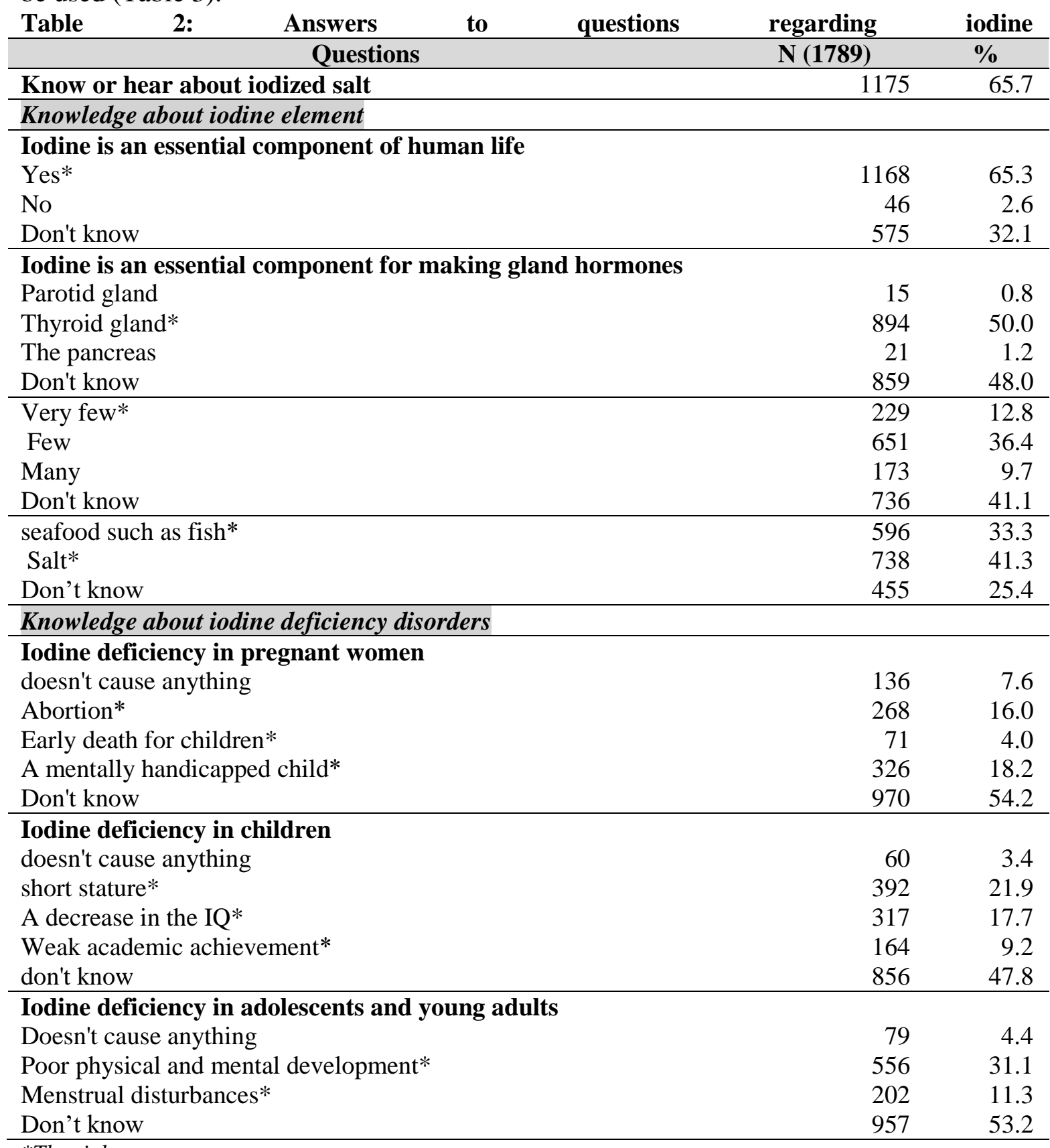

Regarding the practices towards the iodized salt; only $8.0 \%$ of the participants mentioned that they use an opaque

and sealed packaging to keep salt after opening, also, $(67.8 \%)$ of them use a dry spoon and more than one third $(32.9 \%)$ put salt at the end of the cooking process. Most of the participants use the salt bag $(87.1 \%)$ and buy the salt from the supermarket $(80.4 \%)$. Only $35.6 \%$ of the participant care about the producing company (Table 4).

Out of 1789 studied women, 991 (55.4\%) were with a good knowledge score. The knowledge score was significantly higher $(\mathrm{p}$ value $=0.000)$ among the urban people and with 
decreasing in age. The knowledge was significantly good among unmarried females, with an increasing level of education and among the working females especially the governmental employees. The knowledge score also was significantly good with increasing the income $>2000$, with the presence of thyroid disease and hearing about iodized salt ( $\mathrm{p}=0.000)$ (Table 5).

The practice score was significantly good

( $\mathrm{p}$ value $=0.000$ ) among the urban people and with decreasing in age $(p=0.002)$.

The

Table 3: Knowledge about Iodine

\begin{tabular}{|c|c|c|}
\hline Knowledge about iodized salt & $\mathbf{N}$ & $\%$ \\
\hline \multicolumn{3}{|l|}{$\begin{array}{l}\text { How do you identify the } \\
\text { iodine salt bag? }\end{array}$} \\
\hline has a picture of navigation & 198 & 11.1 \\
\hline has a tick Mark & 220 & 12.3 \\
\hline \multirow{2}{*}{\multicolumn{3}{|c|}{ has a tick and navigation mark* }} \\
\hline & 644 & 36.0 \\
\hline & 727 & 40.6 \\
\hline \multicolumn{3}{|l|}{$\begin{array}{l}\text { Is salt affected during storage } \\
\text { by }\end{array}$} \\
\hline Sun and temperature* & 413 & 23.1 \\
\hline Humidity* & 1056 & 59.0 \\
\hline Don't know & 320 & 17.9 \\
\hline \multicolumn{3}{|l|}{$\begin{array}{l}\text { Do you know what a healthy } \\
\text { salt bag would look like? }\end{array}$} \\
\hline $\begin{array}{l}\text { Tightly closed during purchase } \\
\text { or storage }\end{array}$ & 1253 & 70.0 \\
\hline Not petrified & 359 & 20.1 \\
\hline both* & 99 & 5.5 \\
\hline Not tightly closed & 4 & 0.2 \\
\hline Petrified & 18 & 1.0 \\
\hline don't kno & 56 & 3.1 \\
\hline
\end{tabular}

\begin{tabular}{lrr}
\hline $\begin{array}{l}\text { Thinking about how we can } \\
\text { conserve salt after opening the }\end{array}$ & & \\
$\begin{array}{l}\text { bag } \\
\text { Transparent packaging }\end{array}$ & 113 & 6.3 \\
$\begin{array}{l}\text { Opaque packaging } \\
\text { Sealed packaging }\end{array}$ & 60 & 3.4 \\
$\begin{array}{l}\text { Transparent and sealed } \\
\text { packaging }\end{array}$ & 579 & 31.2 \\
Opaque and sealed packaging* & 347 & 32.0 \\
Don't know & 138 & 7.4 \\
\hline Taking salt from the package & & \\
by & & \\
Dry spoon* & 1538 & 86.0 \\
Not dry spoon & 72 & 4.0 \\
Don't know & 179 & 10.0 \\
\hline
\end{tabular}

\begin{tabular}{lrr}
\hline Salt should be placed in food & & \\
At the beginning of cooking & 173 & 9.7 \\
During cooking & 811 & 45.3 \\
At the end of the cooking & & \\
process* & 657 & 36.7 \\
Don't know & 148 & 8.3 \\
\hline
\end{tabular}

Total knowledge score 5.98 \pm 2.9

practice score was significantly good among unmarried females $(\mathrm{p}=0.002)$, with an increasing level of education, among the working females especially the government employees and private workers. The practice score also was significantly $\quad(p=0.001)$ good with increasing the income $>2000$ and with hearing about iodized salt $(\mathrm{p}=0.000)$, however there no significant difference with the presence of a history of thyroid disease $(\mathrm{p}=0.394)$ (Table 6).

The significant predictors for good knowledge by logistic regression analysis; residence, history of thyroid disease, increasing level of education, and hearing about iodized salt were the significant predictors' associated with good knowledge with odds ratios of $1.116, \quad 2.405 \quad 4.344$ and 11.872 respectively (Table 7 ).

There was a positive correlation (Correlation coefficient $=0.451$ ) between the knowledge and practice scores and the correlation was significant $(\mathrm{p}=0.000)$ (Figure 1)

\section{Discussion}

Iodized salt is the main source of dietary iodine in Egypt. ${ }^{7}{ }^{10}$ In 1995, a national survey indicated an epidemic with goiter and the lower urinary iodine concentration in several regions of Egypt. Despite salt iodization in Egypt, studies reveal that there is prevalence of endemic goiter, and it could be the result of inadequate iodization of salt or high consumption of goitrogenics. Nevertheless, iodine deficiency is a major public health problem in certain areas of Egypt. Several surveys among Egyptian children revealed that there is mild iodine deficiency in $60.6 \%$ of 
children and moderate to severe deficiency in $31.3 \%$; the prevalence of goiter is higher in some regions such as South Sinai. ${ }^{18}$

This is a community-based study that was conducted to determine the knowledge status, factors associated with knowledge and the utilization practices of women on iodized salt in Fayoum governorate. The use of iodized salt by individuals and households is the major approach in the control of iodine deficiency diseases worldwide ${ }^{19}$ so; strengthening salt iodization program improving its monitoring is a crucial step to eradicate the problem. ${ }^{20}$

Our study found that more than twothirds of participants heard or knew about iodine $(65.7 \%)$ and iodized salt, and a slightly lesser percent claimed to knew that iodine is an important element for human nutrition $(65.3 \%)$. On the other hand, it seems that they did not know the meaning, as only less than half of them when asked about where iodine is available, reported salt by $(41.3 \%)$ and more than quarter said they don't know $(25.4 \%)$. This was comparable with what was found in an Indian study ${ }^{1}$ that, $68.9 \%$ of participants heard about iodized salt and $26.7 \%$ replied that it is ordinary common salt with a small quantity of iodine; but less than reported by a study ${ }^{15}$ they mentioned that most of the participants $(93.4 \%)$ were aware of iodized salt.

Regarding women's Knowledge about the importance of iodine although, half of the respondents $(50 \%)$ related the iodine to the thyroid gland however nearly half of the participants did not know the consequences of iodine deficiency disorders in different human life cycle we found also, that less than fifth $(18.2 \%)$ of respondents relates between iodine deficiency during pregnancy and affection of mental abilities of newborn or children this is much higher than what was found in other studies where less than (2\%) knew that iodine deficiency impedes brain development. ${ }^{21-23}$ However De Zoysa et al, 2015 found that $50.8 \%$ knew the connection between iodine and thyroid hormones. Nearly 52\% of pregnant women knew that iodized salt is especially important during pregnancy and the bad consequences of maternal iodine deficiency on their babies.

Regarding knowledge about the identification of iodized salt packets, more than forty percent did not know how to identify the iodized salt packet $(40.6 \%)$, and only $(5.5 \%)$ mentioned how a healthy salt bag would look like. This was slightly higher than reported in India

Table (4) Practices iodized salt.

\begin{tabular}{|c|c|c|}
\hline Questions & $\mathrm{N}(1789)$ & $\%$ \\
\hline $\begin{array}{l}\text { How do you keep the } \\
\text { salt at home after } \\
\text { opening the bag? } \\
\text { sealed packaging } \\
\text { A non-sealed package } \\
\text { A transparent } \\
\text { packaging } \\
\text { An opaque packaging } \\
\text { don't care } \\
\text { opaque and sealed } \\
\text { package* }\end{array}$ & $\begin{array}{l}1046 \\
86 \\
223 \\
124 \\
167 \\
143\end{array}$ & $\begin{array}{l}58.5 \% \\
4.8 \% \\
12.5 \% \\
6.9 \% \\
9.3 \% \\
8.0 \%\end{array}$ \\
\hline $\begin{array}{l}\text { Dry spoon* } \\
\text { Don't care }\end{array}$ & $\begin{array}{l}1213 \\
576\end{array}$ & $\begin{array}{l}67.8 \% \\
32.2 \%\end{array}$ \\
\hline $\begin{array}{l}\text { When do you put salt } \\
\text { during cooking food? } \\
\text { at the beginning of } \\
\text { cooking } \\
\text { During cooking } \\
\text { At the end of the } \\
\text { cooking process* }\end{array}$ & $\begin{array}{l}240 \\
961 \\
588\end{array}$ & $\begin{array}{l}13.4 \% \\
53.7 \% \\
32.9 \%\end{array}$ \\
\hline $\begin{array}{l}\text { What type of salt do } \\
\text { you use? } \\
\text { Packed Salt* } \\
\text { Non packed salt }\end{array}$ & $\begin{array}{l}1558 \\
231\end{array}$ & $\begin{array}{l}87.1 \% \\
12.9 \%\end{array}$ \\
\hline $\begin{array}{l}\text { Which places do you } \\
\text { Buy salt from? } \\
\text { Unknown places } \\
\text { Supermarket* } \\
\text { Don't care }\end{array}$ & $\begin{array}{l}144 \\
1438 \\
207\end{array}$ & $\begin{array}{l}8.0 \% \\
80.4 \% \\
11.6 \%\end{array}$ \\
\hline $\begin{array}{l}\text { Are you sure about } \\
\text { the salt-producing } \\
\text { company } \\
\text { Yes* }\end{array}$ & $\begin{array}{l}637 \\
1152\end{array}$ & $\begin{array}{l}35.6 \% \\
64.4 \%\end{array}$ \\
\hline
\end{tabular}

The mean total practice score was $3.2 \pm 1.3$ 
that less than twenty percent could identify a logo or iodine level printed on the packet. ${ }^{15,22}$

In our study we found that $(55.4 \%)$ of women were with a good knowledge score, this was similar to what reported in Ethiopia as they found that more than half women had good knowledge about iodized salt ${ }^{24}$ and higher than what found in Sudan, they revealed that only (41\%) correctly answered about the knowledge of iodized salt ${ }^{2}$ but too much lower than the results of a study conducted in Ghana. $^{25}$

This study revealed that good knowledge of iodized salt was associated with young age, marital status, urban residence,

Table 5: the relation between knowledge score and participants' characteristics.

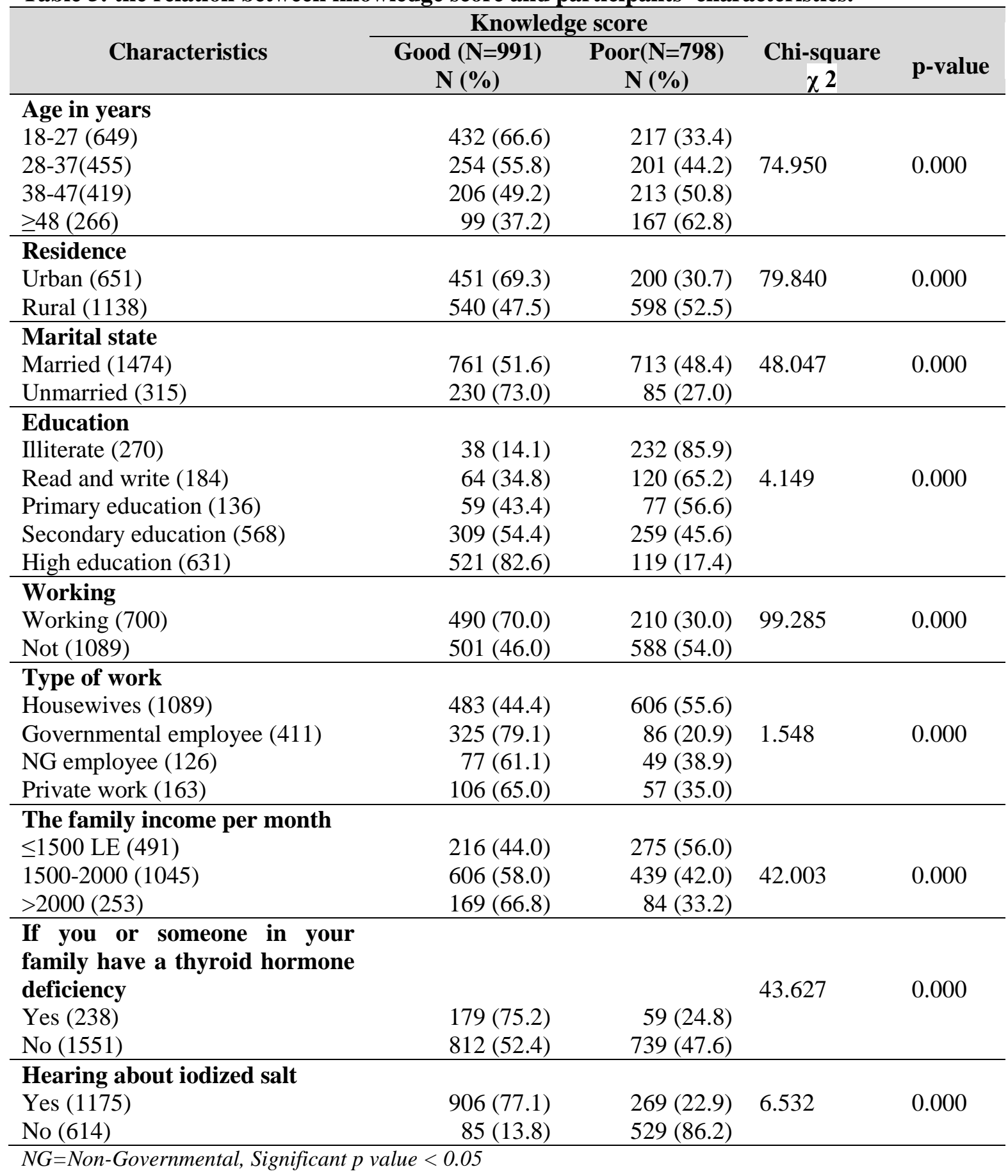


higher educational status, higher family income, have personal or family history of thyroid dysfunctions, and hearing about iodine. This is like Dessu et al., 2018 who stated that higher educational levels and higher family income to be associated with good knowledge. We also found that urban residence, high education level, having a personal or family history of iodine deficiency, and hearing about iodized salt to be

Table 6: The relation between practice score and participants' characteristics.

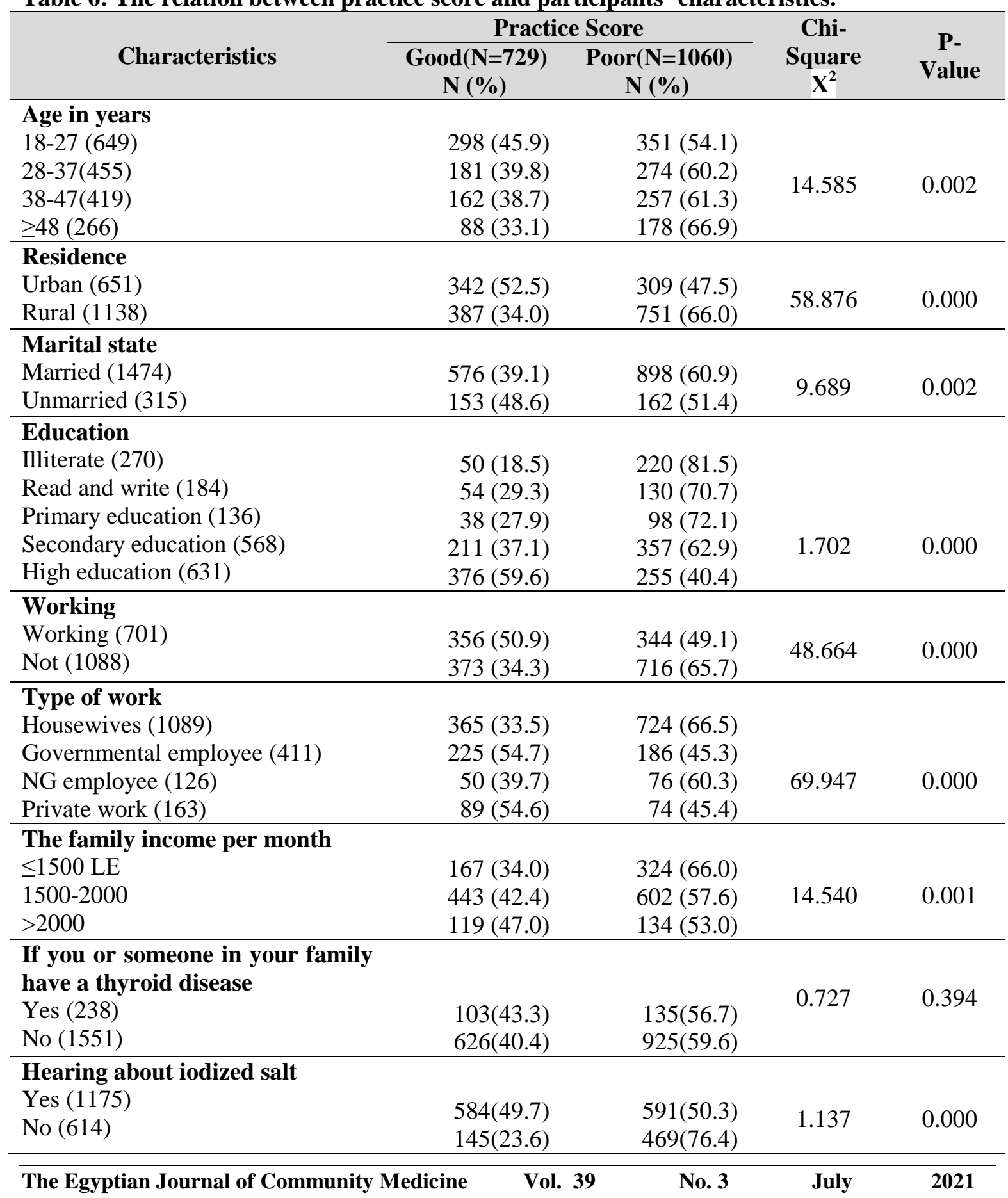

predictors of good knowledge. This might be due to different access to the information system, increased accessibility of the television and radio, and more accessibility of electronic media in urban societies. It may also be due to variation in educational activities and increased motivation to know and become aware 
$N G=$ non-Governmental

iodized salt, its importance, preservation, and use.

salt, we found contradictory results, as compared to the majority of respondents using iodized salt only $8 \%$ keep it in a sealed opaque container and less than the third add it at the end of the cooking process. But more than two-thirds use a dry spoon. This was inconsistent with Karmakar et al., 2019 who found the coverage of USI goal by WHO. ${ }^{7}$

Regarding the different utilization practices to keep the iodine content of

Table 7: Binary logistic regression of predictors of knowledge score.

\begin{tabular}{|c|c|c|c|c|c|}
\hline \multirow[b]{2}{*}{ Variables } & \multirow[b]{2}{*}{ B } & \multirow{2}{*}{$\begin{array}{c}P \text { - } \\
\text { value }\end{array}$} & \multirow{2}{*}{$\begin{array}{l}\text { Adjusted } \\
\text { Odds } \\
\text { ratio }\end{array}$} & \multicolumn{2}{|c|}{ Confidence interval $95 \%$} \\
\hline & & & & Upper limit & $\begin{array}{c}\text { Lower } \\
\text { limit }\end{array}$ \\
\hline Residence (urban versus rural) & 0.374 & 0.006 & 1.453 & 1.116 & 1.893 \\
\hline $\begin{array}{ll}\text { Education } \\
\text { - } \quad \text { Illiterate (reference) } \\
\text { - } \quad \text { Secondary education } \\
\text { - } \quad \text { High education }\end{array}$ & $\begin{array}{l}0.577 \\
1.469\end{array}$ & $\begin{array}{l}0.018 \\
0.001\end{array}$ & $\begin{array}{l}1.781 \\
4.344\end{array}$ & $\begin{array}{l}1.104 \\
2.564\end{array}$ & $\begin{array}{l}2.873 \\
7.358\end{array}$ \\
\hline $\begin{array}{l}\text { History of iodine deficiency } \\
\text { (Yes, versus no) }\end{array}$ & 0.877 & 0.001 & 2.405 & 1.621 & 3.567 \\
\hline $\begin{array}{l}\text { Hearing about iodized salt } \\
\text { (Yes, versus no) }\end{array}$ & 2.474 & 0.001 & 11.872 & 8.809 & 16.000 \\
\hline
\end{tabular}

Table 8: Binary logistic regression of predictors of practice score.

\begin{tabular}{lccccc}
\multicolumn{1}{c}{ Variables } & B & P-value & $\begin{array}{c}\text { Adjusted } \\
\text { Odds ratio }\end{array}$ & \multicolumn{2}{c}{ Confidence interval 95\% } \\
\cline { 5 - 6 } & & & & Upper limit & Lower limit \\
\hline $\begin{array}{l}\text { Residence } \\
\text { (Urban versus rural) }\end{array}$ & 0.398 & 0.001 & 1.489 & 1.196 & 1.853 \\
\hline $\begin{array}{l}\text { Education } \\
\begin{array}{l}\text { - Illiterate (reference) } \\
\text { - High education }\end{array}\end{array}$ & 0.962 & 0.001 & .2 .616 & 1.659 & 4.123 \\
\hline $\begin{array}{l}\text { Knowledge score } \\
\text { (Good versus bad score) }\end{array}$ & 0.995 & 0.001 & 2.704 & 2.076 & 3.521 \\
\hline $\begin{array}{l}\text { majority (96.3\%) of his } \\
\text { store salt in a dry closed container and }\end{array}$ & $\begin{array}{l}\text { population about the value of iodized salt } \\
\text { and its right handling. }\end{array}$
\end{tabular}
only small percent $(8.9 \%)$ reported salt exposure to sunlight.

\section{Conclusion}

Although most of our studied participants $(87.1 \%)$ use iodized salt, however knowledge about iodine and iodized salt in this study population was not satisfactory and many the subjects had improper practices related to the iodized salt usage this emphasis on the role of health education programs through different means to inform our

\section{References}

1. Karmakar N, Datta A, Nag K, Datta SS, Datta S. Knowledge, attitude, and practice regarding household consumption of iodized salt among rural women of Tripura, India: A mixed-methods study. J Edu Health Promot 2019; 8(1):21-21.

2. Elmanssury AE, Elnour SA, Elmosaad YM. Knowledge and Attitude of Population Towards Iodized Salt in Shendi Locality River Nile State in Sudan. European Scientific Journal 2017; 13(6):312-22. 
3. Lazarus JH. The importance of iodine in public health. Environ Geochem Health 2015; 37(4):605-18.

4. Fiore E, Tonacchera M, Vitti P. Influence of iodization programmes on the epidemiology of nodular goitre. Best Pract Res Clin Endocrinol Metab 2014; 28(4):57788.

5. Biban BG, Lichiardopol C. Iodine Deficiency, Still a Global Problem? Curr Health Sci J 2017; 43(2): 103-11.

6. Podoba J, Racova K, Urbankova H, Srbecky M. Current status of iodine deficiency-related disorders prophylaxis in Slovakia - the life's work of Julian Podoba remained unfinished. Endocrine Regulations 2016; 50(1):3-9.

7. World Health Organization, United Nations Children's Fund, International Council for Control of Iodine Deficiency Disorders. Assessment of iodine deficiency disorders and monitoring their elimination. A guide for program managers. 3rd edition. Geneva: World Health Organization; 2007.

8. Pearce EN, Andersson M, Zimmermann MB. Global iodine nutrition: where do we stand in 2013? Thyroid 2013; 23(5):523-8.

9. El-Zanaty F, Way A. Egypt Demographic and Health Survey. Ministry of Health, ElZanaty and Associates, and Macro International. 2008; 13-22.

10.Egypt Iodine Survey, Summary report. National Survey of Household Iodized Salt Use and Iodine Status among Primary School Children and Pregnant Women in Egypt 2014/2015.

11. Yamamah GA, Kamel AF, Dayem SA, Hussein AS, Salama H. Thyroid volumes and iodine status in Egyptian South Sinai schoolchildren. Archives Med Sci 2013; 9(3): 548-54.

12.Azizi F, Mehran L. Experiences in the prevention, control and elimination of iodine deficiency disorders: a regional perspective. Eastern Mediterranean Health Journal 2004; 10 (6): 761-70.

13.United Nations Development Programme Egypt (UNDP). Egypt Human Development Report 2008. cited 2020 Mars 12 Available from

https://www.eg.undp.org/content/egypt/en/h ome/library/human_development/publicatio n_3.html
14.National Information Center (NIC). Central Agency for Public Mobilization and Statistics; (CAPMAS). cited 2020 Mars 11 Available from https://www.capmas.gov. eg/Pages/populationClock.aspx

15.De Zoysa GE, Hettiarachchi M, Jayathilaka KA, Liyanage KD. Knowledge and practices of iodized salt consumption among pregnant women in Galle district, Galle Medical Journal 2015; 20(1): 10-16.

16. World Bank. Poverty \& Equity Brief. Middle East \& South Africa. Arab Republic of Egypt 2020. Available from www.worldbank.org/poverty.

17.Trading Economics. Egypt Minimum Monthly Wages. Available from. https://tradingeconomics.com/egypt/minimu m-wages

18. Mohammadi M. Azizi F. Hedayati M . Iodine deficiency status in the WHO Eastern Mediterranean Region: a systematic reviewEnviron Geochem Health 2018 ; 40:87-97.

19. Aburto NJ, Abdou M, Candeias V, Wu T, World Health Organization. Effect and safety of salt iodization to prevent iodine deficiency disorders: a systematic review with meta-analyses. Geneva; World Health Organization: 2014.

20.UNICEF. Universal salt iodization in Central and Eastern Europe and the Commonwealth of Independent States: experiences, achievement, and lessons learned during the decade 2000-2009. Geneva: UNICEF Regional Office for CEECIS; 2011.

21.Kumar P, Tiwari VK, Gautam RK. Knowledge, attitude, and behavior regarding the use of iodized salt: An evaluation of the national iodine deficiency disorders control program in India. Int J Sustain Dev 2013; 5:95-106.

22. Gidey B, Alemu K, Atnafu A, Kifle M, Tefera Y, Sharma HR. Availability of adequate iodized salt at the household level and associated factors in rural communities in Laelay Maychew District, Northern Ethiopia: A cross-sectional study. J Nutr Health Sci 2015; 2(1):103.

23.Lowe N, Westaway E, Munir A, Tahir S, Dykes F, Lussier $M$, et al. Increasing awareness and use of iodized salt in a marginalized community setting in 
North-West Pakistan. Nutrients 2015; 79(11):9672-82.

24.Dessu S, Dawit Z, Alemu G. Assessment of Knowledge on Iodized Salt Utilization and Associated Factors among Households in Arba Minch Town, Southern Ethiopia. International Journal of Research Studies in Medical and Health Sciences 2018; 3(12): 17-23.
25.Buxton C, Baguune B. Knowledge and practices of people in Bia District, Ghana, with regard to iodine deficiency disorders and intake of iodized salt. Archives of Public Health 2012; 70(1): 5.

26.Iodine Global Network. Global Iodine Nutrition Scorecard for 2015. Cited 2020 Feb 20 Available from: http://www.ign.org/cm_data/Scorecard_201 5_August_26_new.pdf 